within the Llandovery; if within the latter then the throw must be less than 1,000 feet. It is unlikely to be a considerable fault and certainly is not everywhere a boundary fault.

\title{
REFERENCE
}

Raw, F., 1952. Structure and Origin of the Malvern Hills. Proc. Geol. Ass., Lond., 63, 227-239.

Department of Geology and Mineralogy,

H. G. READING,

UNIVERSITY MUSEUM,

OXFORD.

30th June, 1962.

\section{TORRIDONIAN MICROFOSSILS}

SIR,-In a recent publication, Naumova and Pavlovsky (Doklady Academy of Science, U.S.S.R., Vol. 141, No. 1, 1961) report the discovery of microfossils from Lower Torridonian rocks. As the locality from which the specimens came is not recorded in that paper, it might be as well to state that the specimens were collected from the village of Brochel, Isle of Raasay. The material in question was collected in 1957, after Professor Pavlovsky had suggested, during an excursion in Scotland, that the Torridonian might date from the same period of late-Pre-Cambrian time as the Riphean, which had proved to be fossiliferous.

DePartMent OF GEOLOGY,

ImPerial College of SCIENCE,

J. Sutton. LONDON, S.W. 7.

I4th June, 1962. 